\title{
PROBLEM OF CONSONANT CLUSTERS IN CHINESE ADAPTATIONS OF POLISH SURNAMES
}

\begin{abstract}
A bstract. The paper presents some phonetic-graphic phenomena occurring in the Chinese substitutions of Polish surnames. The work concentrates on simplification of the consonant clusters present in the initials and finals of the syllables constituting Polish family names. Numerous examples of sound additions and sound reductions have been excerpted from the examined material. The sound addition type of changes include anaptyxis and paragoge. The reductive changes are apheresis, syncope and apocope. The research material consists of 668 Polish surnames and their 778 adaptation variants, functioning in the Chinese language.

The submitted deliberations are preceded with a theoretical description of the adaptation process, as well as of the main differences between Polish and Chinese and their writing systems, which significantly influence the final shape of the substitutions being created.
\end{abstract}

\section{INTRODUCTION}

Probably in all languages used around the world, there are two functionally separated word-classes: the class of appellative lexical units, i.e. common nouns (nomina appelativa), also called appellatives, as well as the class of onymic lexical units, i.e. proper names (nomina propria).

Generally speaking, appellatives serve to classify objects existing in extralinguistic reality into series of objects sharing some specific sets of features which make them the same. For example, the noun 'table' describes a series of specified objects: all of them having a top surface and at least one leg or some other columnar base. Furthermore, common nouns combined with, inter alia, a definite article or a demonstrative or possessive pronoun, are used to indicate a particular, individual element of a given series (e.g., 'the table', 'this table', and 'my table').

JoAnNA HrynieWSKA-Department of Sinology on Faculty of Humanities at John Paul II Catholic University of Lublin; address for correspondence-e-mail: heyao@op.pl 
The primary function of proper names is to identify and to individualize objects, i.e. to differentiate referents from one another. The main categories of proper names are anthroponyms (personal names) and toponyms (place names). Both of them are further divided into numerous subdivisions. Among anthroponyms, there are, for example, given names, patronymics, nicknames, pen names, pseudonyms, various titles and family names. The category of toponyms comprises, inter alia, names of uninhabited places (microtoponyms), names of mountains (oronyms), names of bodies of water (hydronyms), names of countries and regions (choronyms) and names of objects existing in urban areas: streets, squares, buildings, etc. (urbanonyms). There are also some more or less separate categories of proper names, for example, names of pets and animals (zoonyms), names of astronomical objects (astronyms) or a broad class of chrematonyms which contains names of material or immaterial products of human cultural activities, such as names of festivals, institutions, literary works or mechanical devices. ${ }^{1}$

\section{ADAPTATION PROCESS}

Languages of the world remain in a continuous communication. This statement is not only valid for the languages used by nations or ethnic groups existing in directly neighboring countries or regions, but also for languages spoken by users being in contact through global mass media andfirst of all-via the Internet.

During interlanguage contacts it is inevitable to transfer lexical units, both appellative and onymic, between two (or even more) languages involved in the communication process. The languages differ from one another in their phonological and grammatical characteristics, it is hence necessary for the lexical units being transferred to undergo a so-called adaptation process.

\footnotetext{
${ }^{1}$ Zofia Kaleta. "Teoria nazw własnych" [The Theory of Proper Names], in: Polskie nazwy własne. Encyklopedia [Polish Proper Names. Encyclopedia), EwA RzETELSKA-FELESZKo (ed.), Kraków: Wydawnictwo Instytutu Języka Polskiego PAN, 2005, p. 15-36; IrEnA KaŁUŻYŃSKA, Chinese Female Namings. Past and Present, Warszawa: Wydawnictwo Agade, 2008, p. 9-10, 14-21; EADEM, "Semantically Transparent Given Names of the Han Nation", in: China Past and Present. New Polish Papers in Chinese Studies, MARCIN JACOBY (ed.), Warsaw: Warsaw University Press, 2010, p. 125-127; ROBERT MrózeK, "Nazwy własne jako przedmiot badawczy onomastyki" [Proper Names as the Study Subject of Onomastics], in: Nazwy własne w języku, kulturze i komunikacji spolecznej [Proper Names in Language, Culture and Social Communication], Robert MrózeK (ed.), Katowice: Wydawnictwo Uniwersytetu Śląskiego, 2004, p. 9-19.
} 
The process of proper names adaptation is divided into three main phases: pre-integration phase, contact phase and post contact phase. In the first phase, a contact between languages is established, yet no borrowings (i.e. transfers) of onymic units occur. During the contact phase, a takeover and inclusion of the proper names into the assuming (integrating) language occur. In the last stage, any direct contact of the communicating languages stops, some further development of the assumed lexical units may, however, still occur. A re-contact between the languages is also possible, which influences further modifications of the assumed material.

For the deliberations submitted in the present paper, the most significant phase of the adaptation process seems to be the second one, i.e. the phase of contact between the communicating languages. Two key stages are distinguished here: a so-called transumption and attraction. At the stage of transumption, the adaptation of the proper name to the assuming language starts and the process of its grammatical integration begins. At the stage of attraction, the onymic unit is system-adjusted to the system of the integrating language. At this point, the process of integration is completed, the result being a grammatically integrated foreign proper name, called an adaptation or a substitution. Depending on the system differences existing between the languages participating in the communication process, the proper name substitution is formed with or without modifications on phonic, semantic, morphemic and/or graphic levels. ${ }^{2}$

\section{DIFFERENCES BETWEEN LANGUAGES}

The above-mentioned adaptation process also applies to Polish proper names which are adapted into various foreign languages including Chinese. Substitutions created during the process of adaptation are phonically (but not semantically, morphemically or graphically) connected with the onymic units functioning in the original language. The reason for it lies in several system differences between the Polish language and the Chinese language, as well as between their writing systems. The language and writing issues are briefly discussed below.

\footnotetext{
${ }^{2}$ BARBARA CZOPEK-KOPCIUCH, Adaptacje niemieckich nazw miejscowych $w$ języku polskim [Adaptations of German Place Names in the Polish Language], Kraków: Instytut Języka Polskiego PAN, 1995, p. 38-42; EADEM, Nazwiska polskie w Zagłębiu Ruhry [Polish Surnames in Ruhr], Kraków: Wydawnictwo Instytutu Języka Polskiego PAN, 2004, p. 45-48.
} 
First of all, Polish and Chinese phonological and phonetic systems show significant differences. Vowels and consonants are pronounced in different ways, and furthermore, there are numerous sounds in both languages with no immediate analogue to be found in the other one. The Polish language offers a rather wide range of syllable initials and finals. The sets of Chinese syllable initials and finals are, on the other hand, considerably limited in their structure. For example, only three consonants ([n], [n] and [ə]) may appear at the end of a Chinese syllable final, like in the monosyllabic words/morphemes xīn [6in] 心 'heart', xiōng [ciuj] 兄 'elder brother' and huàr [xuaə] 画儿 'painting, picture'. There are also numerous restrictions concerning the usage of vowels and consonants in the initial position of a syllable. ${ }^{3}$

All the vowels, both in Polish and in Chinese, are voiced and non-aspirated. There are, however, several significant differences between phonological systems of consonants used in both languages.

In the Polish language, a phonological opposition of voiced and unvoiced consonants is used to differentiate the sounds. Most of the Polish consonants function in oppositional pairs of voiced and unvoiced, for example, [b]- $[\mathrm{p}]$, as in the words bal [bal] 'ball, dance' and pal [pal] 'pole, stake'. There is an exception of eight voiced consonants (and their several positional variants) which do not have any unvoiced analogues. These consonants are: [m] (like in maty [mawi] 'small'), [n] (nos [nos] 'nose'), [n] (nie [ne] 'no, not'), [y] (Kongo [kõngo] 'Congo'), [r] (rower [rover] 'bicycle'), [1] (lalka [lalka] 'doll'), [j] (jajko [jajks] 'egg') and [w] (lawka [wafka] 'bench'). The category of aspirated consonants does not exist in the phonological system of the Polish language. ${ }^{4}$

${ }^{3}$ Paul Kratochvíl, The Chinese Language Today. Features of an Emerging Standard, London: Hutchinson University Library, 1968, p. 32-33, 86; MieCZYSŁAW JERZY KÜNSTLER, Języki chińskie [Chinese Languages], Warszawa: Wydawnictwo Akademickie Dialog, 2000, p. 225-226, 273-274; LiU HongmeI 刘红梅, WU ChUANTAO 武传涛 (ed.), Shiyong Hanyu yuyin 实用汉语语音 [The Practical Chinese Phonetics], Hefei 合肥: Anhui Jiaoyu Chubanshe 安徽教育出版社, 2004, p. 134-140; EWA ZAJDLER, Glottodydaktyka sinologiczna. Optymalizacja procesu nauczania dorostych i testowania bieglości we współczesnym języku chińskim na poziomie podstawowym $w$ glottodydaktyce sinologicznej $w$ polskim środowisku językowym [The Sinological Glottodidactics. Optimization of Adults Teaching Process and of Proficiency Testing in the Modern Standard Chinese at the Elementary Level in the Sinological Glottodidactics of the Polish Language Environment], Warszawa: Wydawnictwo Akademickie Dialog, 2010, p. 24.

${ }^{4}$ Danuta Ostaszewska, Jolanta TAMBOR, Fonetyka i fonologia współczesnego języka polskiego [The Phonetics and Phonology of the Modern Polish Language], Warszawa: Wydawnictwo Naukowe PWN, 2008, p. 35, 102-105; ElŻBIETA SĘKOwSKA, "Fonetyka z elementami fonologii" [Phonetics with Elements of Phonology], in: Nauka o języku dla polonistów [Language 
In the Chinese language, on the other hand, no phonological distinction between voiced and unvoiced consonants is made. The only voiced Chinese

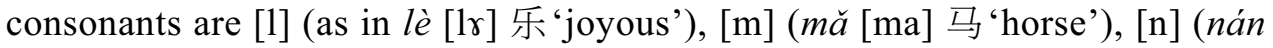
[nan] 难 'difficult') and [z] (rén [zon] 人 'human being'). All other Chinese consonants are unvoiced, although non-aspirated ones may-in certain positions-be partially or almost fully voiced. Some scholars believe there is one phonologically opposing pair of voiced and unvoiced consonants actually existing in the Chinese language: these are, namely, the consonants [z] (rén [zən] 人 'human being') and [s] (shén [sən] 神 'spirit'). Instead of voiced versus unvoiced opposition, Chinese differentiates the sounds on the basis of their aspiration versus non-aspiration feature. There are six oppositional pairs of aspirated and non-aspirated Chinese consonants: [p'] - [p], like in pà [p'a]

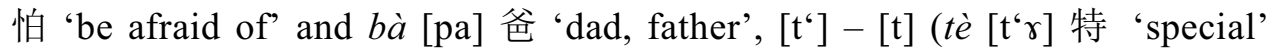

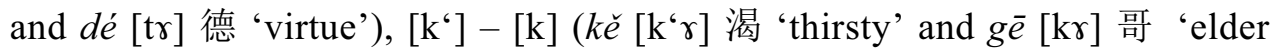
brother'), [ts'] - [ts] (ci [t'c1] 词 'word' and zì [ts] ] 字 'character, written

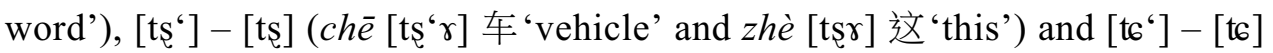
$(q \bar{\imath}$ [t6'i] 七 'seven' and $j \bar{l}$ [tti] 几 'a few, several'). Sometimes a seventh pair, the above mentioned [s] - [z], is also added to this set. The rest of Chinese consonants do not constitute any aspirated and non-aspirated pairs. ${ }^{5}$

The most significant suprasegmental features of the Chinese language are distinctive tones, also called tonemes and tone phonemes. There are four tones used in Modern Standard Chinese: high (as in $m \bar{a}$ [ma] 妈 'mum, mother'), rising ( $m a ́$ 麻 'hemp'), low ( $m a \check{~ 马 ~ ' h o r s e ') ~ a n d ~ f a l l i n g ~(~} m a ̀$ 骂 'curse'). Each Chinese syllable may theoretically be pronounced in one of the four tones, changing not only its pronunciation, but also its meaning. It is, however, noticed in practice that the usage of tones is restricted, i.e. not every syllable may be given all the four tonemes. The most important fact to be emphasized at this point is that the tones are an integral part of Chinese pronunciation and of the phonetic/phonological system of the Chinese language. On the other hand, there is no tone phonemes occurrence of any kind in the Polish language system. ${ }^{6}$

Studies for Polish Scholars], StanisŁaw Dubisz (ed.), Warszawa: Książka i Wiedza, 2002, p. 119, 121-123.

${ }^{5}$ Kratochvíl, The Chinese Language Today, p. 25-27; KüNSTLER, Języki chińskie, p. 224225; ZAJDLER, Glottodydaktyka sinologiczna, p. 22.

${ }^{6}$ Kratochvíl, The Chinese Language Today, p. 35-37; Künstler, Języki chińskie, p. $227-$ 230; LiU, Wu, Shiyong Hanyu, p. 89-99, 126-129; ZAJDLER, Glottodydaktyka sinologiczna, p. 24-28. 
There are also considerable structural disparities between Polish and Chinese syllables. Each syllable needs to contain at least one kernel or one syllable centre. This obligatory kernel-both in Polish and in Chinese-has to be a syllabic phone, i.e. a vowel. There are two basic types of syllables: open and closed ones. An open syllable's final is a vowel whereas a closed one ends with a consonant or a group of consonants. ${ }^{7}$

In the Polish language, two kinds of open syllables and two kinds of closed ones are used. The open ones' structures are (1) /obligatory vowel/ and (2) /non-obligatory initial consonant(s)/ + /obligatory vowel/. Apt examples here may be the initial syllables of the words (1) a-niot [anow] 'angel' and (2) ba-gaż [bagaf] 'luggage'. The closed syllables' structures are (3) /obligatory vowel/ + /obligatory final consonant(s)/ and (4) / non-obligatory initial consonant(s)/ + /obligatory vowel/ + /obligatory final consonant(s)/. This type of structures are present, for example, in the initial syllables of the words (3) ab-so-lut [apsolut] 'absolute' and (4) bez-dom-ny [bezdomni] 'homeless'. ${ }^{8}$ Most of the Polish syllables belong to the open structure pattern. There is, nevertheless, one factor which makes the Polish syllable structure fairly complex: it is namely the extremely common presence of consonant clusters. These clusters are made of two or three consonants and placed either in the initial or in the final position of a syllable. There are about 724 consonant clusters used in the modern Polish language. The monosyllabic words stót [stuw] 'table' and karp [karp] 'carp' may serve as fitting examples of two-consonant clusters in the initial and in the final position of a syllable. Three-consonant clusters are placed, for example, in the initial and in the final position of the monosyllabic words szkto [Jkwo] 'glass' and barszcz [barfty] 'borscht'. It is often possible to divide a Polish word into syllables in two different ways, with or without breaking an initial consonant cluster. For example, the word matka [matka] 'mother' may be divided into two syllables, either mat-ka or ma-tka, the second method of division including a two-consonant cluster [tk]). The choice of either of the two correct forms depends on the language user. ${ }^{9}$

\footnotetext{
${ }^{7}$ Ostaszewska, TAmbor, Fonetyka i fonologia, p. 27; AdAm WeinsBerg, Językoznawstwo ogólne [General Linguistics], Warszawa: Państwowe Wydawnictwo Naukowe, 1983, p. 254-256.

${ }^{8}$ Tadeusz Milewski, Językoznawstwo [Linguistics], Warszawa: Państwowe Wydawnictwo Naukowe, 1967, p. 218.

${ }^{9}$ Hanna DalewSKa-Greń, Języki stowiańskie [Slavic Languages], Warszawa: Wydawnictwo Naukowe PWN, 2002, p. 156-157; BARBARA WIERZCHOWSKA, Opis fonetyczny języka polskiego [The Phonetic Description of the Polish Language], Warszawa: Państwowe Wydawnictwo Nau-
} 
The set of Chinese syllables is limited to merely 408 units, each giving a theoretical possibility to be pronounced in one of the four above-mentioned tones. 235 of them belong to the open-structure syllables, whereas 173 are closed syllables. Their basic structures are similar to the Polish syllables. The open ones' structures are (1) /obligatory vowel, (triphthongized) diphthong, or triphthong/ and (2) /non-obligatory initial consonant/ + /obligatory vowel/. Two apt examples of this kind of structures are the words/morphemes (1) ̀̀ [r] 饿 'hungry' and (2) fă [fa] 法 'law'. The closed syllables' structures are (3) /obligatory vowel, (triphthongized) diphthong, or triphthong/ + /non-obligatory final consonant/ and (4) /non-obligatory initial consonant/ + /obligatory vowel, (triphthongized) diphthong, or triphthong/ + /non-obligatory final consonant/. These two syllable types are represented, for example, by the words/morphemes (3) ān [an] 安 'peaceful' and (4) dòng [tun] 动 'move'. There is no occurrence of consonant clusters either in Chinese syllables' initials or finals, and thus dividing a word into syllables is clear and a separation of syllables from one another may be done easily. Furthermore, Chinese (unlike Polish) belongs to the group of monosyllabic languages, that is to say, in most cases one separate syllable corresponds to one morpheme, i.e. a smallest meaningful unit comprised of a group of phonemes. There are also Chinese morphemes bigger and smaller than a syllable, but meaningful monosyllables surely are one of distinctive features of the Chinese language. ${ }^{10}$

Apart from the above-mentioned differences between both languages, there are also significant disparities between the writing systems they use. The most obvious one is that the Polish writing system is an alphabetical script, whereas Chinese speakers use an ideographic, i.e. a non-alphabetical type of script. The most complex and important features of both writing systems are briefly discussed below.

The Polish alphabet includes nine letters modified by diacritical marks.

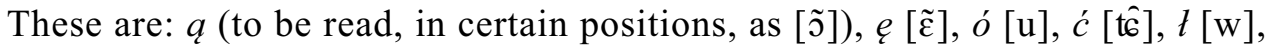
$\dot{n}[\mathrm{n}], \dot{s}[\mathrm{6}], \dot{z}[\mathrm{z}]$ and $\dot{z}[3]$. There are also seven digraphs and one trigraph in

kowe, 1967, p. 172-173; EADEM, Fonetyka i fonologia języka polskiego [The Phonetics and Phonology of the Polish Language], Wrocław: Ossolineum, 1980, p. 131-132.

${ }^{10}$ Kratochvíl, The Chinese Language Today, p. 24-34, 55; KüNSTLER, Języki chińskie, p. 15-16; LiU, Wu, Shiyong Hanyu, p. 11-12; MilewsKi, Językoznawstwo, p. 210; Ewa ZaJdLer, Marcin Jacoby, Qian Li-PiszczeK, Współczesny język chiński. Mówić i pisać po chińsku [Modern Standard Chinese. To Speak and to Write in Chinese], Warszawa: Wydawnictwo Akademickie Dialog, 2008, vol. 1, p. 286-287. 
the Polish script, namely: $c h$ (read as [x], or, extremely rarely, as $[\gamma]), c z[\hat{\mathfrak{f}}]$,

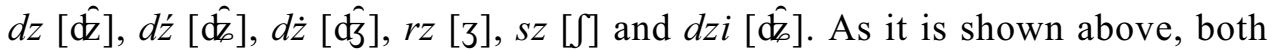
the digraph $d z$ and the trigraph $d z i$ should be read in the same way, as the consonant $[\hat{d}]$. There are also four letter combinations denoting same sounds as four of the letters with diacritical points. These are: $c i[\hat{\epsilon}], n i[\mathrm{n}]$, $s i[6]$ and $z i[z]$. The choice of the letters with diacritics or the letter combinations is determined by the specific rules of the Polish grammar. Besides, two other letter groups ( $g i$ and $k i$ ), having no analogues among the letters with diacritical signs, should also be read as consonants ([f] and [c]).

The presence of letters modified by diacritical marks, letter combinations and digraphs (and one trigraph) in the Polish script results in frequent occurrence of a linguistic phenomenon: there is a discrepancy between the number of sounds in speech and the number of letters in writing. Two situations are possible here: either the letters outnumber the sounds uttered, or the number of phones exceeds the number of letters. The first situation occurs when there is at least one digraph, one letter combination or the trigraph $d z i$ present in a word. For example, in the word dzieci [zॄtcii] 'children' there are six letters, but only four phones. The second situation requires the presence of the letter $a$, $e$ or $\dot{n}$ in a word, i.e. a letter with diacritical point. For example, in the word stońce [swõjntŝ] 'sun' there are seven phones, but only six letters. ${ }^{11}$

The Chinese writing system belongs to the ideographic kinds of scripts. That is to say that its writing units, i.e. the Chinese characters, symbolize abstract or substantial concepts. Almost every character represents a semantically independent lexical unit - a morpheme or a word. For example, the character $天$ is a graphical indicator of-among other meanings-'heaven' and the character 好 denotes the adjective 'good'. What should be stressed at this point is that graphical forms of Chinese characters do not record sounds, i.e. the phonetic shapes of semantic units; instead, they denote meanings in one way or another. From the graphical forms of both characters mentioned above it is impossible to deduce that their pronunciation is tiān [t'ion] and hăo [xao]. Nonetheless, there is a large group of so-called pictographicphonetic characters. Graphical units of this kind are the most numerous and constitute about $70-80 \%$ of all the Chinese characters. This class comprises characters built of two elements, first of which denoting a semantic category

${ }^{11}$ DalewsKa-Greń, Języki stowiańskie, p. 590; OstasZewSKA, TAMBOR, Fonetyka i fonologia, p. 57-62; SĘKOWSKA, Fonetyka z elementami, p. 140. 
(meaning) and the second one being connected with a phonetic category (pronunciation). An apt example here may be the Chinese character 柏. Its first element (木) denotes the lexical units 'tree, wood' and indicates a high possibility of a close connection of the character 柏 with semantic categories of botany, flora, plants' variety, etc. The second element (白), pronounced as bái [pai], is a phonetic indication of the possible proper pronunciation of the whole lexical unit represented in writing by the character 柏. In this case both the semantic and the phonetic indication are correct: the character 柏 denotes the word/morpheme 'cypress', pronounced as băi [pai]. It should nevertheless be emphasized that the existence of the pictographic-phonetic characters class does not bring the Chinese script any closer to any of the phonetic writing systems used around the world. First of all, the Chinese pronunciation has substantially changed throughout centuries of the language development. Because of it, the phonetic indications included in the characters - once useful and correct - often turn out to be misleading and incorrect at a given stage of the language evolution. Secondly, as the discussed example of the character 柏 shows, the above-named elements of a character cannot ever serve as a credible indication as to which of the four tones should be used with a given lexical unit. ${ }^{12}$

\section{RESEARCH MATERIAL}

The conclusions included in the present paper are based upon research material consisting of 668 Polish family names and their 778 adaptation variants existing in the Chinese language. The adaptations have been selected from four different sources. These are:

(1) Names of the World's Peoples. Shijie renming fanyi da cidian 世界人名翻译大辞典, edited by Guo Guorong 郭国荣, published in 1993 by Zhongguo Duiwai Fanyi Chuban Gongsi 中国对外翻译出版公司 in Beijing. This dictionary of anthroponyms contains 65000 adaptations of given names and surnames functioning in over a hundred countries and regions around the world. For the purpose of the present paper, there were 533 substitutions

\footnotetext{
${ }^{12}$ Kratochvíl, The Chinese Language Today, p. 146-148; KünSTler, Języki chińskie, p. 47-48; ZuO MiN'AN 左民安 (ed.), Xishuo Hanzi - 1000 ge Hanzide qiyuan yu yanbian 细说汉字 - 1000个汉字的起源与演变 [A Description of Chinese Characters - Origins and Evolution of One Thousand Characters], Beijing 北京: Jiuzhou Chubanshe 九州出版社, 2005, p. 13.
} 
excerpted from the dictionary, which constitute $68,51 \%$ of the whole research material.

(2) Bolan wenxue 波兰文学 (Polish Literature), by Yi Lijun 易丽君, published in 1999 by Waiyu Jiaoxue yu Yanjiu Chubanshe 外语教学与研 究出版社 in Beijing. The work concentrates on history of Polish literature, from the $10^{\text {th }}$ century until the early nineties of the $20^{\text {th }}$ century. 62 adaptations were taken out from this source, which make $7,97 \%$ of the examined material.

(3) Bolan ershi shiji shixuan 波兰二十世纪诗选 (An Anthology of the $20^{\text {th }}$ Century Polish Poetry), by the same author, Yi Lijun 易丽君, published in 1992 by Shanghai Yiwen Chubanshe 上海译文出版社 in Shanghai. The publication is a collection of 127 poems by 24 contemporary Polish authors. 13 substitutions were searched out from the work, i.e. $1,67 \%$ of the whole material.

(4) The last source of the selected adaptations were various websites accessible via the Internet. These were, inter alia: Wikipedia, news services, portals on culture, arts, hobbies, and sports, forums on foreign languages and translations, as well as official governmental websites of the People's Republic of China (PRC). There were 170 substitutions excerpted from this source, which constitute $21,85 \%$ of all cases.

The overwhelming majority of the examined surnames are onymic lexical units written and pronounced in accordance with the rules of Polish grammar. It should be stressed, however, that the choice of the family names was not based upon their genetic origins. The research material comprises, for example, several proper names of Germanic origin, e.g., 'Brandstaetter' [brantfteter]. For the purpose of the present paper, the term "Polish surnames" is therefore understood as "the surnames used by Polish people".

The research material includes family names used by men, women and grammatically suitable for users representing both sexes. Among the 668 Polish family names excerpted, there were 379 surnames of masculine gender, i.e. ending with suffixes $-c k i,-d z k i$ or $-s k i$, which make $56,74 \%$ of all the proper names in question. The family names of feminine gender, i.e. ending with suffixes -cka and -ska, constitute a group of 91 units, being 13,62\% of the whole material. The remaining 198 proper names $(29,64 \%$ of all cases) are grammatically neutral, and thus may be used by both genders.

The submitted deliberations are illustrated with 18 examples of Polish surnames and their adaptations in the Chinese language. 


\section{TECHNICAL REMARKS}

(1) In the present paper, the pronunciation of proper names' adaptations is based upon the pronunciation of lexical units of Modern Standard Chinese.

(2) Chinese characters are written in simplified forms.

(3) Two methods of notation are used in transcription of the exemplary Polish surnames. The first one is an ordinary letter notation, commonly used on a daily basis. Next to it, there is an International Phonetic Alphabet transcription in square brackets, in the shape as it was chosen by the editors of a Polish pronunciation dictionary. ${ }^{13}$ In both notations the family names are divided into syllables.

(4) Exemplary Chinese substitutions are given in three forms. The first one is the Chinese Phonetic Alphabet (Hànyǔ pinnyinn 汉语拼音) with a graphic representation of one of the four tones. When a syllable/syllables corresponding to a particular Chinese character may be pronounced with more than one tone, all the possible variants are included in the romanized notation. The second form, given in square brackets, is the International Phonetic Alphabet transcription, in the shape as it is usually presented by editors of Chinese-English dictionaries published in PRC. ${ }^{14}$ In both notations the adaptations are divided into syllables. Lastly, the third form is the notation in Chinese characters. Next to it, in brackets, one will find a symbol of the source, from which the example is selected. These are: GUO 1993, YI 1999 and YI 1992 for the three above-mentioned publications and the letter 'I' for the Internet sources.

\section{CHINESE ADAPTATIONS OF POLISH SURNAMES}

The above-discussed differences between the two languages and their writing systems result in formation of various substitutions on phoneticgraphic level. There are three points pertaining to the adaptation process of

\footnotetext{
${ }^{13}$ Mieczysław Karaś, Maria Madejowa (eds.), Slownik wymowy polskiej [A Dictionary of Polish Pronunciation], Warszawa-Kraków: Państwowe Wydawnictwo Naukowe, 1977.

${ }^{14}$ See e.g.: WeI Dongya 危东亚 (ed.), Han-Ying cidian. A Chinese-English dictionary 汉英词典, Beijing 北京: Waiyu Jiaoxue yu Yanjiu Chubanshe 外语教学与研究出版社, 2003, p. 1715-1717.
} 
Polish family names to the Chinese language, that merit special attention. These are:

(1) Syllable boundaries of Polish surnames and their Chinese substitutions run through different points. It is thus very common, that one Polish syllable is replaced by two or even more Chinese syllables. Occasionally, a reverse phenomenon occurs: a Polish syllable is entirely or partially removed, which results in a considerable simplification of an adaptation compared with the family name it originates from.

(2) Creators of Chinese substitutions are usually unfamiliar with the pronunciation of the letters modified by diacritical marks, the letter combinations and the digraphs (and one trigraph) used in the Polish language. More often then not, they ignore the diacritical signs and tend towards breaking the digraphs and the trigraph into separate letters, later pronounced as individual phones, i.e. single consonants or vowels.

(3) In order to transcribe a Polish adaptation into the Chinese language, it is necessary to use Chinese characters in the secondary function of phonetic symbols. That is to say, the creators of substitutions use the Chinese characters being graphical indicators of words/morphemes phonetically as close as possible - at least theoretically - to the pronunciation of syllables or syllable elements constituting the original proper names. The semantic meaning of the chosen words/morphemes therefore becomes insignificant or is at least relegated to the second place. For example, the creator of an adaptation of the Polish surname 'Bensch' [benf] has given it the form of 'Běn-shī [pən-sl] 本施' (GUO 1993). The meanings of the word/morpheme bèn [pən], written with the character 本, are: 1 . the root or stem of a plant; 2 . foundation, basis, origin; 3. capital, principal; 4. major, central; 5. originally, at first; 6. one's own, native; 7. current, this, present; 8 . be based on; 9. book; 10 . manuscript, copy; 11. script; 12. edition, version; 13. measure word for books, parts of a serial, etc. ${ }^{15}$ The meanings of the second word/morpheme $s h \bar{l}$ [s]], noted with the character 施, are: 1. bring (or put) into effect, execute, carry out; 2 . bestow, grant, hand out; 3 . exert, impose; 4. use, apply; 5. a surname ${ }^{16}$. The meanings of both words/morphemes are in fact irrelevant for the usage of the substitution in the Chinese language. From this point of view, the most important part is their pronunciation. In other words, one could as well use units běn [pən] and shī [sl] written with any other charac-

\footnotetext{
${ }^{15}$ Ibid., p. 52.

${ }^{16}$ Ibid., p. 1108.
} 
ters and carrying different meanings, e.g., the character 畚 for běn [pən] and the character 诗 for $s h \bar{\imath}$ [sl], meaning 'a bamboo or wicker scoop' and 'poetry, verse, poem' ${ }^{17}$, respectively. The usage of Chinese characters as phonetic symbols results in numerous distortions of original lexical units, there is, however, no other method of incorporating them into the grammatical system of the Chinese language.

\section{CONSONANT CLUSTERS}

Consonant clusters occurred 884 times in the 668 examined Polish family names. There are 105 various clusters excerpted from the whole research material, each present in at least one of the examined family names. The consonant clusters may be divided into four classes. These are:

(1) Clusters formed of two consonants, corresponding in writing to two letters, e.g., [3m] $\dot{z} m-$, like in the surname 'Żmu-da' [3mu-da]. This is the broadest class, comprising 68 types of clusters which constitute $64,76 \%$ of all cases.

(2) Clusters formed of two consonants, corresponding in notation to three letters. For example, [b3] brz-, as in 'Brzech-wa' [bzex-fa]. This group includes 23 types of clusters $(21,90 \%)$.

(3) Clusters comprising two consonants, corresponding to two or three letters. An apt example here may be the cluster [xr]. It is present in the surname 'Hry-niak' [xri-nak], as well as in the surname 'Chro-now-ski' [xronof-sci], in the shape of two $(h r-)$ and three letters $(c h r-)$, respectively. This limited class includes only four cases $(3,81 \%)$.

(4) Clusters built of three consonants, written with three letters, e.g., [zbr] $z b r$-, like in the family name 'Zbro-żek' [zbro-zek]. This group comprises six types of clusters $(5,71 \%)$.

There are also four types of clusters remaining beyond the abovementioned classes. Each of them includes only one separate case which make $0,95 \%$ of all cases. These are:

(1) The cluster [nf] -nsch, formed of two consonants corresponding to four letters. There is only one example of a surname containing this cluster: 'Bensch' [benf].

${ }^{17}$ Ibid., p. 54, 1107. 
(2) The cluster [ $[\hat{\mathfrak{f}}]$, made of two consonants, written with three or four

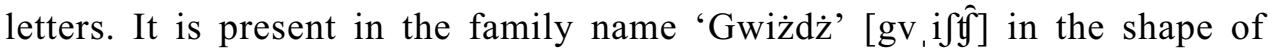
three letters, $-\dot{z} d \dot{z}$. The same cluster may also be noted with four letters $(-s z c z)$, as in the surname 'Droszcz' [droft̂]].

(3) The cluster [zg3] zgrz-, built of three consonants and noted with four letters. The single example of a family name comprising this cluster is 'Zgrzy-wa' [zgzi-va].

(4) The cluster $\left[\mathrm{r} \int \hat{\mathfrak{y}}\right]-r s z c z$, formed of three consonants, written with five letters. The only example of a surname containing this cluster is 'Barszcz' [barfî].

\section{PHENOMENA OBSERVED}

The analysis of the substitutions of Polish surnames in the Chinese language has shown various phonic and phonetic phenomena occurring in the course of the adaptation process. The present paper concentrates on the kind of changes taking place in the initials and finals of the syllables constituting Polish family names. A point that surely merits special attention are the above-discussed consonant clusters. These groups of consonants are extremely common in Polish, but the phenomenon does not occur in Chinese. Because of it, every time a Chinese substitution of a Polish proper name comprising such a consonant cluster is formed, a need arises to simplify it by breaking it or by removing a part of it. The changes leading to such simplifications are sound additions and sound reductions. The sound addition type of changes noticed during the analysis of the research material are anaptyxis and paragoge. The reductive changes include apheresis, syncope and apocope. A phenomenon of sound replacements, occurring usually simultaneously with sound additions and sound reductions, has also been found in the examined material.

\subsection{SOUND ADDITIONS-EPENTHESIS}

Epenthesis is an addition of a so-called epenthetic sound to a lexical unit. ${ }^{18}$ It serves to simplify a consonant cluster by breaking it. In the research

${ }^{18}$ Terry Crowley, An Introduction to Historical Linguistics, Suva: University of Papua New Guinea Press, University of the South Pacific, 1987, p. 33; JACEK Perlin, Metodologia 
material it is an extremely common change, occurring 902 times in 757 adaptations which constitute $97,30 \%$ of all cases. That is to say, a simultaneous occurrence of epenthesis in more than one point of a substitution is not unusual. Anaptyxis and paragoge are two types of epenthetic changes appearing in the examined material. Several examples of these phenomena shall be submitted below.

\subsubsection{ANAPTYXIS}

Anaptyxis is - generally speaking - an occurrence of a so-called anaptyctic vowel between two other sounds of a lexical unit. ${ }^{19}$ For the purpose of the present paper, however, the term anaptyxis shall be understood as an insertion of a vowel, a vowel-semivowel group or a vowel-consonant group between two consonants. This phenomenon occurred 818 times in 709 examples which make $91,13 \%$ of the examined material.

In the research material anaptyxis was used to break 85 consonant clu-

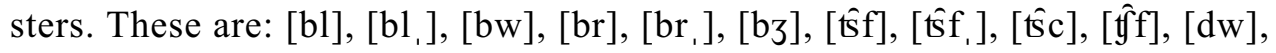
$[\mathrm{dm}],[\mathrm{dr}],[\mathrm{dv}],[\mathrm{d} 3],[\mathrm{ftc}],\left[\mathrm{fl} l_{1}\right],[\mathrm{fr}],[\mathrm{f} J],[\mathrm{gl}],[\mathrm{gl}],,[\mathrm{gw}],[\mathrm{gr}],[\mathrm{gv}],,[\mathrm{g} 3]$, $[\mathrm{xr}],[\mathrm{xs}],[\mathrm{xt}],[\mathrm{jm}],[\mathrm{jn}],[\mathrm{jt}],[\mathrm{kf}],[\mathrm{kw}],[\mathrm{kr}],[\mathrm{ks}],[\mathrm{kst}],[\mathrm{kJ}],[\mathrm{wk}],[\mathrm{wn}]$, $[\mathrm{mp}],[\mathrm{mps}],[\mathrm{pw}],[\mathrm{pr}],[\mathrm{p} f],[\mathrm{pt}],\left[\mathrm{r} \int \hat{\mathfrak{f}}\right],[\mathrm{st \hat {s }}],[\mathrm{sk}],[\mathrm{skw}],[\mathrm{sc}],[\mathrm{sw}],[\mathrm{sm}]$, [sp], [sr], [st], [str], [ $\left.\int \hat{\mathfrak{y}}\right],\left[\int \mathrm{f}\right],\left[\int \mathrm{k}\right],\left[\int \mathrm{m}\right],\left[\int \mathrm{p},\right],\left[\int \mathrm{t}\right],[6 \mathrm{f}],,[\mathrm{tf}],[\mathrm{tr}],[\mathrm{t} f],[\mathrm{vd}]$, [vw], [vn], [vr], [wz], [v3], [zb.], [zbr], [zd], [zg], [zgl, ], [zg3], [zm], [zn], $[\mathrm{zv}],[\mathrm{zv}],,\left[\mathrm{zd}_{\mathrm{b}}\right],[3 \mathrm{~m}]$ and $\left[3 \mathrm{v}_{1}\right]$.

In the analyzed adaptations, the most commonly occurring example of anaptyxis is breaking the cluster [sc] by inserting an anaptyctic vowel [1] or a vowel-semivowel group [ai] (written in bold in the following example). The case appeared 428 times, for instance:

(1) Pol. Bis-kup-ski [b,is-kup-sci]—Chin. Bǐ-sāi/sī-kù-pǔ-sāì/sī-j̄̄i [pisai/s1-k'u-p'u-sai/s1-tci] 比斯库普斯基 (GUO 1993).

A second most common case is simplifying the cluster [sk] with the vowel and the vowel-semivowel group mentioned above. Such a change occurred 94 times, e.g.:

językoznawstwa diachronicznego [Methodology of Historical Linguistics], Warszawa: Wydawnictwo Akademickie Dialog, 2004, p. 103, 306; KAZIMIERZ POLAŃSKI (ed.), Encyklopedia językoznawstwa ogólnego [An Encyclopedia of General Linguistics], Wrocław-Warszawa-Kraków: Zakład Narodowy im. Ossolińskich, 1995, p. 135.

${ }^{19}$ Perlin, Metodologia językoznawstwa, p. 103, 295; PolAŃSKI, Encyklopedia językoznawstwa, p. 46. 
(2) Pol. Ka-mień-ska [ka-m,ej-ska]—Chin. Kă/Qiă-míng-sāi//sī-kă/qiă [k'a/t6'a-min-sai/s1-k'a/t6'a] 卡明斯卡 (YI 1992)

Another very frequently occurring case is breaking the cluster [dr] by the insertion of the vowel $[\gamma]$ between two consonants. This kind of anaptyxis occurred 37 times, for example:

(3) Pol. Droz-dow-ski [droz-dəf-sci]—Chin. Dé-luó-cí/zī-duō-fū/fú-sāi/ sī-jī [tr-luo-ts ' ${ }^{2} /$ ts]-tuo-fu-sai/s]-tci] 德罗兹多夫斯基 (GuO 1993).

In the research material, there is also a peculiar type of anaptyxis: an anaptyctic vowel is used to break a digraph into separate letters (pronounced as individual consonants) instead of breaking a consonant cluster. Anaptyxis of this kind occurred only twice, each time in a case involving the digraph $r z$ [3] and the anaptyctic vowel [?], for instance:

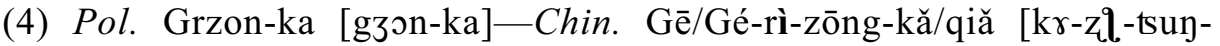
$k^{\prime} a / t^{\prime}$ 'a] 格日宗卡 (I).

\subsubsection{PARAGOGE}

The second type of epenthesis, called paragoge, is an extension of a consonantal final of a syllable with an additional vowel. ${ }^{20}$ For the present deliberations this term was, nonetheless, expanded to a syllable final extension with a vowel, a vowel-semivowel group or a vowel-consonant group. This type of change occurred 84 times in 80 substitutions which constitute $10,28 \%$ of the whole material.

In the analyzed adaptations, paragoge was used to simplify 36 consonant clusters. These are: [dr], [ff], [xs], [xt], [jd], [jm], [js], [jt], [ks], [kst], [1k],

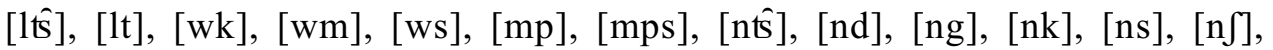

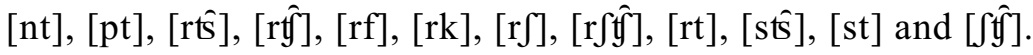

The most frequently occurring example of paragoge is extending the cluster [rt] by adding the vowel $[\gamma]$ in the final position. The case appeared 15 times, for example:

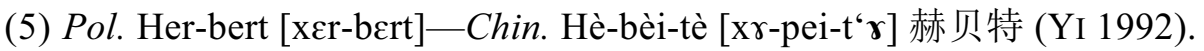

The second most common case is extending the cluster [nt] with the above-mentioned vowel. Such a change occurred 13 times, for instance:

(6) Pol. Put-ra-ment [put-ra-ment]—Chin. Pǔ-tè-lā/lá/lă/là-mén-tè [p“u$t^{6} \gamma$-la-mən- $t^{6} \gamma$ ] 普特拉门特 (YI 1999).

${ }^{20}$ WOLFGang PöCKL, Franz RAInER, Einführung in die romanische Sprachwissenschaft [An Introduction to Romance Linguistics], Tübingen: Niemeyer, 1990, p. 59. 
Another rather commonly appearing case is extending the cluster [1t] by addition of the vowel $[\gamma]$ to the syllable final. This kind of paragoge occurred six times, e.g.:

(7) Pol. In-feld [in-felt]—Chin. Yīn-fèi’ěr-dé [jin-fei’ð-tr] 因费尔德 (Guo 1993).

\subsection{SOUND REDUCTIONS—LOSS OF A SOUND}

Sound reductions manifest themselves with a loss of a sound or sounds in a lexical unit. ${ }^{21}$ In the research material reductive changes pertain to single consonantal sounds. They serve to simplify consonant clusters by removing some elements of them. Such a phenomenon is not common in the examined material. It was found in 29 adaptations which constitute $3,73 \%$ of all cases. Each time there was only one occurrence of a sound reduction in a substitution noticed. There are three types of reductive changes-apheresis, syncope and apocope-excerpted from the material. Several examples of these phenomena shall be discussed below.

\subsubsection{APHERESIS}

Apheresis is usually defined as a loss of a sound or sounds in the initial position of a lexical unit. ${ }^{22}$ In the present paper, however, this term mainly refers to a loss of a single consonant in the initial position of a syllable. This kind of apheresis appeared in 14 adaptations which is $1,80 \%$ of all examples.

In the examined material apheresis was used to simplify three consonant clusters. These are: $[\mathrm{d} 3],[\mathrm{t}]$ ] and [vw].

The most commonly occurring case of apheresis is removing the consonant $[\mathrm{v}]$ (written in bold in the following example) from the initial position of the cluster $[\mathrm{vw}]$. Such change appeared eight times, for instance:

(8) Pol. Włod-kow-ski [vwot-kof-sci]—Chin. Wò-dé-kē-fū/fú-sāi/sī-jī [wuo-tr-k' $\gamma$-fu-sai/s]-tci] 沃德科夫斯基 (GUO 1993).

The second type of apheresis, in order of frequency, is simplifying the cluster [d3] by the removal of the consonant [d]. The case occurred five times, e.g.:

\footnotetext{
${ }^{21}$ Perlin, Metodologia językoznawstwa, p. 98-100, 323; PolAŃSKI, Encyklopedia językoznawstwa, p. 443.

${ }^{22}$ Perlin, Metodologia językoznawstwa, p. 100, 294; POLAŃSKI, Encyklopedia językoznawstwa, p. 18.
} 


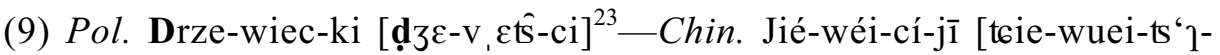
tci] 杰维茨基 (GUO 1993).

The last type of apheresis is removing the consonant [t] from the cluster $[\mathrm{t}]$. Apheresis of this kind occurred only once:

(10) Pol. Kos-trze-wa [kos-t $\left.\int \varepsilon-v a\right]^{24}-C h i n$. Kē-sāi/sī-qiē/qiè-wá $\left[k^{6} \gamma\right.$ sai/s1-t6“ie-wua] 科斯切娃 (GUO 1993).

\subsubsection{SYNCOPE}

Syncope is generally described as a loss of a vowel or a syllable in the middle position of a lexical unit. ${ }^{25}$ For the purpose of the present deliberations, nevertheless, this definition was limited to a loss of a single consonant or a semivowel in the middle position of a syllable. In the analyzed substitutions a syncope occurred in merely nine examples which make $1,16 \%$ of the whole material.

In the research material, syncope was used to simplify four consonant clusters. These are: [bw], [br], [rf] and [rt].

The most frequently occurring case of syncope is simplifying the cluster [rt] by removing the consonant $[\mathrm{r}]$ from its initial position. This kind of syncope appeared five times, for example:

(11) Pol. La-chert [la-xert]—Chin. Lā/Lá/Lă/Là-hè-tè [1a-x $\left.\gamma-t^{6} \gamma\right]$ 拉赫特 (GuO 1993).

The second most common case is removing the consonant $[\mathrm{r}]$ from the cluster [rf]. Syncope of this type occurred merely twice, for instance:

(12) Pol. Wal-dorff [val-dorf]—Chin. Wă/Wà'ěr-duō-fū/fú [wua'or-tuo$\mathrm{fu}$ ] 瓦尔多夫 (GUO 1993).

The third kind of syncope is a simplification of the cluster [br] by removal of the consonant $[\mathrm{r}]$ from it. In the examined material, there is only one example of such a change:

(13) Pol. Bro-no-wic-ki [bro-no-v, itŝ-ci]—Chin. Bō-nú-yù-jī [po-nu-jyt6i] 波奴域基 (I).

${ }^{23}$ In the example given, there is an alveolar variant of the consonant [d] used, written as [d]. Another correct pronunciation of the cluster noted with the letters drz- is [dj3], with the affricative [d̂̉]. See e.g.: KARAś, MADEJOWA, Stownik, p. LVII.

${ }^{24}$ In the example given, there is an alveolar variant of the consonant $[\mathrm{t}]$ used, noted as [t]. Another correct pronunciation of the cluster written with the letters $t r z$ - is [t]f $]$, with the affri-

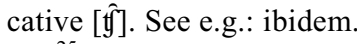

${ }^{25}$ Crowley, An Introduction, p. 30; Perlin, Metodologia językoznawstwa, p. 100, 327; POLAŃSKI, Encyklopedia językoznawstwa, p. 533. 
Syncope of the last type involves the cluster [bw]. It is an exceptional case of this reductive change, because the element removed is not a consonant, but a semivowel $[\mathrm{w}]$, used in the consonantal function. In the whole material, this kind of syncope occurred only once:

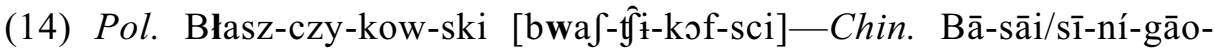
sāi/sī-jī [pa-sai/sp-ni-kao-sai/s1- tci] 巴斯尼高斯基 (I).

\subsubsection{APOCOPE}

Apocope is basically defined as a loss of a vowel or a syllable in the final position of a lexical unit. ${ }^{26}$ For the purpose of the present paper, however, this term refers to a loss of a single consonant in the final position of a syllable. Apocope as it is hereby defined is an extremely rare phenomenon: it applies to no more than six adaptations which constitute merely $0,77 \%$ of all cases.

In the analyzed substitutions, apocope was used to simplify three consonant clusters. These are: [ng], [nt] and [rt].

The most frequently occurring case of apocope is simplifying the cluster [nt] by removing the consonant [t] from its final position. Such a change appeared four times, e.g.:

(15) Pol. Zey-land [zej-lant]—Chin. Zé-lán [tsr-lan] 泽兰 (GuO 1993).

Apocope involving the cluster [ng] occurred only once. The cluster was simplified by the removal of the consonant $[\mathrm{g}]$ :

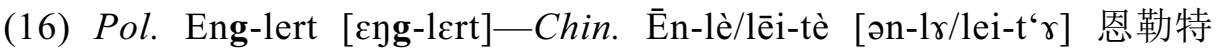
(GUO 1993).

The last type of apocope also appeared merely once. The consonant [ $t]$ was removed from the final position of the cluster [rt]:

(17) Pol. Ry-chard [rì-xart]—Chin. Lǐ-qià’ěr [li-to'iA' ’] 里恰尔 (I).

\section{CONCLUSIONS}

The presented paper should be perceived as an attempt of a concise description of phonetic-graphic phenomena found in the Chinese adaptations of Polish surnames. The submitted deliberations concentrate on several me-

${ }^{26}$ Crowley, An Introduction, p. 29-30; PerLIN, Metodologia językoznawstwa, p. 100, 296; Polański, Encyklopedia językoznawstwa, p. 49. 
thods of simplifying consonant clusters present in Polish family names, commonly applied in the process of entering them into the Chinese language system.

The phonetic changes briefly described above are a complex matter and the simultaneity of their occurrence makes them even more complicated. Apart from the simultaneous occurrence of numerous sound additions and sound reductions in a single substitution, a presence of various above-mentioned sound replacements is also an extremely common phenomenon. The following example may be illustrative of this variety of changes:

(18) Pol. An-drze-jew-ski [ạ̣-ḍze-jef-sci]—Chin. Ān-jié-yē/yé-fū/fú-sāi/ sī-jī [an-tcie-jie-fu-sai/sp-tci] 安杰耶夫斯基 (GUO 1993).

In the adaptation, the original consonants $-r z-[3]$ and $-k-[\mathrm{c}]$ were replaced by the consonants $-j i-$ [tci] and $-j-$ [t6], respectively. In the second syllable an apheresis occurred: the consonant cluster $-d r z-$ [d] $]$ has been simplified by removing the consonant $-d-[\mathrm{d}]$ from its initial position. There has been an occurrence of a paragoge in the third syllable - the consonantal final $-w$ - [f] has been extended by adding the vowel $-\bar{u} / u^{\prime}-[\mathrm{u}]$. Finally, in the last syllable an anaptyxis appeared: the consonant cluster $-s k-[\mathrm{sc}]$ has been broken by the insertion of an anaptyctic vowel-semivowel group [ai] or a vowel [1].

The simultaneity and diversity of numerous phonetic-graphic changes occurring in several positions of a single substitution shall be the subject of the future work.

\section{BIBLIOGRAPHY}

Crowley, Terry. An Introduction to Historical Linguistics. Suva: University of Papua New Guinea Press, University of the South Pacific, 1987.

CZOPEK-KopCIUCH, BARBARA. Adaptacje niemieckich nazw miejscowych w języku polskim [Adaptations of German Place Names in the Polish Language]. Kraków: Instytut Języka Polskiego PAN, 1995.

CzOPeK-Kopciuch, Barbara. Nazwiska polskie w Zagłębiu Ruhry [Polish Surnames in Ruhr]. Kraków: Wydawnictwo Instytutu Języka Polskiego PAN, 2004.

DalewsKa-Greń, HannA. Języki słowiańskie [Slavic Languages]. Warszawa: Wydawnictwo Naukowe PWN, 2002.

Kaleta, Zofia. "Teoria nazw własnych" [The Theory of Proper Names]. In: Polskie nazwy własne. Encyklopedia [Polish Proper Names. Encyclopedia), EwA RZETELSKA-FeleszKo (ed.). Kraków: Wydawnictwo Instytutu Języka Polskiego PAN, 2005, p. 15-36.

KaŁuŻyŃSKA, IRENA. Chinese Female Namings. Past and Present. Warsaw: Wydawnictwo Agade, 2008. 
KaŁUŻYŃSKA, IRENA. "Semantically Transparent Given Names of the Han Nation." In: China Past and Present. New Polish Papers in Chinese Studies, MARCIN JACOBY (ed.), Warsaw: Warsaw University Press, 2010, p. 125-127.

Karaś, MieczysŁaw, \& Maria Madejowa (eds.). Slownik wymowy polskiej [A Dictionary of Polish Pronunciation]. Warszawa-Kraków: Państwowe Wydawnictwo Naukowe, 1977.

Kratochvíl, Paul. The Chinese Language Today. Features of an Emerging Standard. London: Hutchinson University Library, 1968.

KÜNSTLER, MieCZySŁaw JeRZy. Języki chińskie [Chinese Languages]. Warszawa: Wydawnictwo Akademickie Dialog, 2000.

LiU, HongmeI 刘红梅, \& Wu ChUANTAO 武传涛 (ed.). Shiyong Hanyu yuyin 实用汉语语音 [The Practical Chinese Phonetics]. Hefei 合肥: Anhui Jiaoyu Chubanshe 安徽教育出版社, 2004, p. 134-140.

Milewski, TAdeusz. Językoznawstwo [Linguistics]. Warszawa: Państwowe Wydawnictwo Naukowe, 1967.

MrÓzeK, ROBERT. "Nazwy własne jako przedmiot badawczy onomastyki" [Proper Names as the Study Subject of Onomastics]. In: Nazwy własne w języku, kulturze i komunikacji społecznej [Proper Names in Language, Culture and Social Communication], RoBERT MrózeK (ed.). Katowice: Wydawnictwo Uniwersytetu Śląskiego, 2004, p. 9-19.

Ostaszewska, Danuta, \& Jolanta TAmBor. Fonetyka i fonologia wspólczesnego języka polskiego [The Phonetics and Phonology of the Modern Polish Language]. Warszawa: Wydawnictwo Naukowe PWN, 2008.

PerLIN, JACEK. Metodologia językoznawstwa diachronicznego [Methodology of Historical Linguistics]. Warszawa: Wydawnictwo Akademickie Dialog, 2004.

PöCKL, WOlfGANG, \& FRANZ RAINER. Einführung in die romanische Sprachwissenschaft [An Introduction to Romance Linguistics]. Tübingen: Niemeyer, 1990.

PolAŃSKI, KAZIMIERZ (ed.). Encyklopedia językoznawstwa ogólnego [An Encyclopedia of General Linguistics]. Wrocław-Warszawa-Kraków: Zakład Narodowy im. Ossolińskich, 1995.

SęKowsKa, ElżBiETA. "Fonetyka z elementami fonologii" [Phonetics with Elements of Phonology]. In: Nauka o języku dla polonistów (Language Studies for Polish Scholars), StanisŁaw DuBISZ (ed.). Warszawa: Książka i Wiedza, 2002, p. 119, 121-123.

WeI, Dongya 危东亚 (ed.). Han-Ying cidian. A Chinese-English dictionary 汉英词典. Beijing 北京: Waiyu Jiaoxue yu Yanjiu Chubanshe 外语教学与研究出版社, 2003.

Weinsberg, AdAm. Językoznawstwo ogólne [General Linguistics]. Warszawa: Państwowe Wydawnictwo Naukowe, 1983.

WierzChOWSKA, BARBARA. Fonetyka i fonologia języka polskiego [The Phonetics and Phonology of the Polish Language]. Wrocław: Ossolineum, 1980.

WierzchowsKa, BARBARA. Opis fonetyczny języka polskiego [The Phonetic Description of the Polish Language]. Warszawa: Państwowe Wydawnictwo Naukowe, 1967.

ZAJDLER, EWA, MARCIN JACOBY, \& QIAN LI-PISZCZEK. Wspótczesny język chiński. Mówić i pisać po chińsku [Modern Standard Chinese. To Speak and to Write in Chinese], vol. 1. Warszawa: Wydawnictwo Akademickie Dialog, 2008.

ZAJDLER, EWA. Glottodydaktyka sinologiczna. Optymalizacja procesu nauczania dorostych i testowania biegłości we współczesnym języku chińskim na poziomie podstawowym $w$ glottodydaktyce sinologicznej w polskim środowisku językowym [The Sinological Glottodidactics. Optimization of Adults Teaching Process and of Proficiency Testing in the Modern Standard Chinese at the Elementary Level in the Sinological Glottodidactics of the Polish Language Environment]. Warszawa: Wydawnictwo Akademickie Dialog, 2010. 
ZuO, MiN’AN 左民安 (ed.). Xishuo Hanzi - 1000 ge Hanzide qiyuan yu yanbian 细说汉字 1000 个汉字的起源与演变 [A Description of Chinese Characters-Origins and Evolution of One Thousand Characters). Beijing 北京：Jiuzhou Chubanshe 九州出版社, 2005.

\section{PROBLEMATYKA ZBITEK SPÓŁGŁOSKOWYCH W CHIŃSKICH ADAPTACJACH POLSKICH NAZWISK}

Streszczenie

Artykuł prezentuje pewne zjawiska fonetyczno-graficzne występujące w chińskich substytucjach polskich nazwisk. Praca koncentruje się na uproszczeniu zbitek spółgłoskowych w nagłosowych i wygłosowych sylabach polskich nazwisk. $Z$ materiału badawczego zostały zaczerpnięte liczne przykłady zmian o charakterze rozszerzeniowym i redukcyjnym. Wśród zmian rozszerzeniowych znalazły się anaptyksa i paragoga. Zmiany redukcyjne to afereza, synkopa i apokopa. Materiał badawczy składa się z 668 polskich nazwisk oraz 778 ich wariantów adaptacyjnych, funkcjonujących w języku chińskim.

Właściwe rozważania są poprzedzone teoretycznym opisem procesu adaptacji, a także głównych różnic między językami polskim i chińskim oraz systemami ich zapisu, które znacząco wpływają na ostateczny kształt powstających substytucji.

Key words: Polish surnames, Chinese substitutions, consonant clusters, anaptyxis, paragoge, apheresis, syncope, apocope.

Słowa kluczowe: polskie nazwiska, chińskie substytucje, zbitki spółgłoskowe, anaptyksa, paragoga, afereza, synkopa, apokopa. 